\title{
EUROPEAN FUNDS FOR RURAL AREAS VERSUS REGIONAL CONVERGENCE OF AGRICULTURE IN POLAND
}

\author{
Mieczysław Adamowicz, Full Professor ${ }^{1}$ \\ Faculty of Economics and Technical Sciences, Pope John Paul II State School of Higher Education in Biała Podlaska
}

\begin{abstract}
The objective of the work is the assessment of the phenomenon of convergence of agriculture in the provinces/voivodeship (NUTS 2) in Poland in the years 2003-2014 in relation to the use of European funds designated for development of agriculture and rural areas. The study specified dimensions of support under the European Funds granted for agriculture and rural areas in individual regions, which were compared to the size of gross added value of agriculture, forestry, hunting and fishery. Within the analysis, data of the Agency for the Restructuring and Modernisation of Agriculture as well as The Local Data Bank of Central Statistical Office were used. Data regarding productivity of agriculture and other rural sectors in the regions as well as data on the used resources from the European funds were availed of in the assessment of the correlation between these expectations and the phenomena of sigma-convergence and beta-convergence in the regional system. The conducted analysis confirmed the occurrence of a phenomenon of convergence in the tested scope.
\end{abstract}

Keywords: convergence, rural areas, European Funds JEL codes: R11, R12

\section{INTRODUCTION}

Countries which joined European Union in 2004, located in the Central-Eastern Europe, had a significantly lower level of GDP per inhabitant at the time of accession than countries that had already been members of the European Community. Differences in the level of income, reflecting the differences in the level of economic development of former and new member states created the possibilities of revealing the phenomenon of convergence. The convergence, meaning the reduction of development disproportions between the member states created them in the regions is one of the main goals of European integration and the key instrument of its reaching is the inflow of community funds from the budget by means of different EU funds supporting the policies and development strategies which refer to economic sections, regions and countries.

Agriculture, characterized by low productivity of the labour factor, functioning in diverse natural and social-economic conditions, strongly supported by common agricultural policy is a sector with a significant convergence potential. The objective of the work is the assessment of the phenomenon of convergence of agriculture and other natural sectors of rural economy in the provinces of Poland in 2003-2014 and its relation with the use of EU funds designated for the development of agriculture and rural areas. Statistics were elaborated by Adam Szepeluk.

${ }^{1}$ Corresponding author: Sidorska 95/97, 21-500 Biała Podlaska, adamowicz.mieczyslaw@gmail.com, +48 509166658 


\section{MATERIALS AND METHODS}

In order to obtain the assumed goal the dimensions of support granted for the agriculture and rural areas in individual regions must be specified, along with the methods of measurement of the state of development of agriculture in the regions, as well as elaboration of the essence and the methods of measuring the convergence phenomenon.

Data concerning the use of EU funds were obtained from Modernisation of Agriculture as well as Local Data Bank of Central Statistical Office. The level of use of resources covers, above all, all agricultural funds which finance Objectives I and II of the Pillar of Common Agricultural Policy. The analysis assumed the sum of funds for direct payments towards agriculture and subsidies from the Cohesion Fund for the development of rural areas (Adamowicz and Szepeluk, 2018).

The results as well as the level of development of agriculture in individual regions may be specified by means of various indexes and indicators (Sapa and Nawrocka, 2014). The indicator which displays the results obtained by agriculture, forestry, hunting and fishery, measured by means of gross added value was assumed in the study.

Convergence, constituting a decrease in disproportions occurring between regions, at best by acceleration of development of delayed regions may be considered in the form of sigma-convergence, beta-convergence as well as club convergence (Czyżewski and Kułyk, 2009; Sapa and Bear-Nawrocka, 2014; Smędzik-Ambroży, 2014; Hamulczuk, 2015; Barath Ferto, 2017; Adamowicz and Szepeluk, 2018). Sigma-convergence defines the scale of disproportions in a given phenomenon in time, mainly from the beginning to the end of the researched period. Its measure is the variance and standard deviation (Wójcik, 2008). Beta-convergence defines the tempo of increase of the researched indicator in individual regions in time. The occurrence of beta-convergence signifies the occurrence of a phenomenon of making up for the lagging in the weaker developed regions against the regions with initially higher development indexes. The club convergence is of conditional nature and occurs in groups of regions featured by a certain similarity of results or development factors.

Apart from an attempt to define the size of the phenomenon of convergence, also correlation account was applied within the work between the level of gross added value (GAV) and the size of the obtained funds in PLN from the European Funds (EF).

\section{RESULTS}

Polish agriculture and rural areas availed of the support from PHARE and ISPA programmes even in the pre-accession period. After becoming a member state, sources of funding expanded as well as the level of funding which increased. Average value of the obtained funds per province from the UE funds by agriculture increased from the level of approx. PLN 188 million in 2004 to approx. PLN 1,744 million in 2015. In the period of 2004-2014 an increase tendency may be observed with certain slumps in the years 2007, 2012, 2014.

In 2004, with an average of PLN 188 million per province, the largest funds were obtained by the following provinces: Mazowieckie (PLN 348 million) and Lubelskie (PLN 340 million), while Lubuskie obtained PLN 35 million and Zachodniopomorskie obtained PLN 82 million. In 2014, the biggest beneficiaries with an average of PLN 1,632 per province were the following provinces: Mazowieckie (PLN 3,949 million), Wielkopolskie (PLN 2,828 million) and Lubelskie (PLN 2,675) (Adamowicz and Szepeluk, 2018).

The comparison of the gross added value and the values of the obtained funds from the EU funds by individual provinces revealed the fact that in the first year of membership the average gross added value exceeded ten times the value of obtained funds falling on average per one province. The GAV ration to the volume of the obtained European Funds was at the level of 3.76 in the Podkarpackie province, to 24.66 in the Lubuskie province. In 2014 the average indicator of GAV per value of the obtained funds was at the level of 1.57 , ranging within the limits between 0.8 in the Podkarpackie province to 2,26 in the Mazowieckie province (Table 1). 
Proceedings of the 2018 International Scientific Conference 'Economic Sciences for Agribusiness and Rural Economy' No 1, Warsaw, 7-8 June 2018, pp. 212-220

Table 1. Dynamics of the distribution of gross added value calculated for the obtained funds from the EU funds in 2004-2014 by province (PLN)

\begin{tabular}{|l|c|c|c|c|c|c|c|c|c|c|c|}
\hline Specification & 2004 & 2005 & 2006 & 2007 & 2008 & 2009 & 2010 & 2011 & 2012 & 2013 & 2014 \\
\hline Dolnośląskie & 7.78 & 2.43 & 1.73 & 2.25 & 1.43 & 1.34 & 1.64 & 1.51 & 1.23 & 1.20 & 1.28 \\
\hline Kujawsko-pomorskie & 8.45 & 2.77 & 1.51 & 2.29 & 1.48 & 1.52 & 1.54 & 1.77 & 1.45 & 1.64 & 1.61 \\
\hline Lubelskie & 5.34 & 1.87 & 1.32 & 1.78 & 1.45 & 1.24 & 1.42 & 1.60 & 1.27 & 1.35 & 1.18 \\
\hline Lubuskie & 24.66 & 2.72 & 1.64 & 2.90 & 1.54 & 1.64 & 2.00 & 1.74 & 2.00 & 1.65 & 1.71 \\
\hline Lódzkie & 12.04 & 3.09 & 2.37 & 3.00 & 2.35 & 2.83 & 2.12 & 2.13 & 1.91 & 1.72 & 2.01 \\
\hline Małopolskie & 6.44 & 3.02 & 2.25 & 3.53 & 2.59 & 2.76 & 2.15 & 1.96 & 1.73 & 1.50 & 1.30 \\
\hline Mazowieckie & 14.26 & 3.54 & 2.30 & 3.40 & 2.83 & 2.59 & 2.55 & 2.44 & 2.46 & 2.46 & 2.26 \\
\hline Opolskie & 7.62 & 2.74 & 2.15 & 2.32 & 1.52 & 1.54 & 1.72 & 1.60 & 1.81 & 1.44 & 1.31 \\
\hline Podkarpackie & 3.76 & 1.78 & 1.31 & 1.93 & 1.71 & 1.61 & 1.17 & 1.11 & 0.96 & 0.98 & 0.81 \\
\hline Podlaskie & 10.22 & 2.07 & 1.10 & 2.26 & 1.35 & 1.60 & 1.44 & 1.30 & 1.70 & 1.66 & 1.53 \\
\hline Pomorskie & 5.91 & 1.75 & 1.17 & 2.09 & 1.22 & 1.35 & 1.30 & 1.39 & 1.58 & 1.27 & 1.55 \\
\hline Śląskie & 9.59 & 3.34 & 3.02 & 3.67 & 3.47 & 3.17 & 2.76 & 2.26 & 2.02 & 1.93 & 1.90 \\
\hline Świętokrzyskie & 7.24 & 2.58 & 1.75 & 2.39 & 2.17 & 2.04 & 1.65 & 1.67 & 1.46 & 1.33 & 1.35 \\
\hline Warmińsko-mazurskie & 11.58 & 2.38 & 1.34 & 2.16 & 1.46 & 1.48 & 1.85 & 1.76 & 1.81 & 1.47 & 1.87 \\
\hline Wielkopolskie & 17.81 & 3.40 & 2.28 & 2.88 & 1.85 & 2.18 & 2.17 & 1.85 & 1.88 & 2.00 & 2.13 \\
\hline Zachodniopomorskie & 17.47 & 2.00 & 1.75 & 2.07 & 1.28 & 1.25 & 1.61 & 1.14 & 1.54 & 1.19 & 1.41 \\
\hline Average & 10.64 & 2.59 & 1.81 & 2.56 & 1.86 & 1.88 & 1.82 & 1.70 & 1.68 & 1.55 & 1.57 \\
\hline
\end{tabular}

Source: own elaboration on the basis of data from Agency for Restructuring and Modernization of Agriculture and Local Data Bank of Central Statistical Office.

Relative gross added value calculated into the funds obtained from the EU funds (GAV/EF) in 2004 reached the highest value in case of Lubuskie province (248.3\%) Wielkopolskie province (179.2\%) and Zachodniopomorskie (175.8\%). The lowest GAV/EF value in 2004 was noted by Podkarpackie province (37.9\%), Lubelskie province $(53.8 \%)$ and Pomorskie province $(59.5 \%)$. This diversification stems mainly from the diverse use of the pre-accession funds SAPARD. After the accession and covering the entire agriculture with the financing form the European Funds, these disproportions were significantly decreased. Between 2004-2014 the average GAV/EF value dropped from the level of 107.1 to $94.7 \%$, with the highest values in 2014 obtained by Mazowieckie province (136.1\%), Wielkopolskie province (127.8\%) and Łódzkie (120.9\%). When in 2004 extreme values of indicators increased from 37.9\% (Podkarpackie province) to $248.3 \%$ (Lubuskie province), then in 2014 the extreme values decreased to the value from $48.7 \%$ (Podkarpackie province) to $136.1 \%$ (Mazowieckie province) - Table 2.

When analysing the three year's means at the beginning and at the end of the researched period the largest positive change of the indicator GAV/EF was felt by the following provinces: Pomorskie $(+37.9$ p.p.), Wielkopolskie $(+30.3$ p.p.) and Podlaskie $(+20.6$ p.p.). Negative change covered almost half of the provinces, including Lubuskie ( -27.5 p.p.), Dolnośląskie (-16.8 p.p.) and Małopolskie (-10.9 p.p.) - Table 3.

Median of the change amounted to: -9.5 p.p. which indicates the fact that half of the tested provinces diminished the analysed indicator by -9.5 p.p. 
Proceedings of the 2018 International Scientific Conference 'Economic Sciences for Agribusiness and Rural Economy' No 1, Warsaw, 7-8 June 2018, pp. 212-220

Table 2. Dynamics of distribution of the level of gross added value translated into the obtained EU funds with regards to the country scale by province $(\%)$

\begin{tabular}{|l|c|c|c|c|c|c|c|c|c|c|c|}
\hline Specification & 2004 & 2005 & 2006 & 2007 & 2008 & 2009 & 2010 & 2011 & 2012 & 2013 & 2014 \\
\hline Dolnośląskie & 78.4 & 90.4 & 96.3 & 87.2 & 77.2 & 71.9 & 88.7 & 85.7 & 71.1 & 72.5 & 77.0 \\
\hline Kujawsko-pomorskie & 85.1 & 103.0 & 84.3 & 88.7 & 79.7 & 81.9 & 83.1 & 100.4 & 84.0 & 99.0 & 96.8 \\
\hline Lubelskie & 53.8 & 69.5 & 73.7 & 68.9 & 78.3 & 66.7 & 76.6 & 91.0 & 73.7 & 81.6 & 70.8 \\
\hline Lubuskie & 248.3 & 101.0 & 91.1 & 112.4 & 83.4 & 88.6 & 108.0 & 99.0 & 115.8 & 100.2 & 103.1 \\
\hline Lódzkie & 121.2 & 114.9 & 131.9 & 116.2 & 126.7 & 152.7 & 114.5 & 121.2 & 110.9 & 104.2 & 120.9 \\
\hline Małopolskie & 64.8 & 112.3 & 125.1 & 136.6 & 139.8 & 148.4 & 116.2 & 111.4 & 100.6 & 90.6 & 78.2 \\
\hline Mazowieckie & 143.5 & 131.6 & 128.3 & 131.5 & 153.0 & 139.3 & 137.6 & 138.6 & 142.5 & 149.0 & 136.1 \\
\hline Opolskie & 76.7 & 101.8 & 119.5 & 89.8 & 82.1 & 82.9 & 92.8 & 90.8 & 104.8 & 87.1 & 78.9 \\
\hline Podkarpackie & 37.9 & 66.2 & 73.0 & 74.7 & 92.6 & 86.7 & 63.2 & 63.2 & 55.9 & 59.2 & 48.7 \\
\hline Podlaskie & 102.9 & 77.2 & 61.3 & 87.6 & 72.9 & 86.4 & 77.8 & 73.7 & 98.6 & 100.4 & 92.1 \\
\hline Pomorskie & 59.5 & 65.3 & 64.9 & 80.8 & 65.6 & 72.5 & 70.1 & 78.7 & 91.7 & 76.9 & 93.0 \\
\hline Śląskie & 96.6 & 124.2 & 168.1 & 142.0 & 187.5 & 170.6 & 149.2 & 128.6 & 117.1 & 117.0 & 114.1 \\
\hline Świętokrzyskie & 72.9 & 96.0 & 97.2 & 92.6 & 117.4 & 110.1 & 89.1 & 95.1 & 84.8 & 80.5 & 81.1 \\
\hline Warmińsko-mazurskie & 116.6 & 88.4 & 74.4 & 83.4 & 78.7 & 79.5 & 100.1 & 100.1 & 105.2 & 88.8 & 112.5 \\
\hline Wielkopolskie & 179.2 & 126.4 & 126.7 & 111.6 & 99.9 & 117.6 & 117.3 & 105.2 & 108.8 & 121.1 & 127.8 \\
\hline Zachodniopomorskie & 175.8 & 74.3 & 97.3 & 80.1 & 69.2 & 67.5 & 87.0 & 64.9 & 89.5 & 72.1 & 84.5 \\
\hline Average & 107.1 & 96.4 & 100.8 & 99.0 & 100.2 & 101.5 & 98.2 & 96.7 & 97.2 & 93.8 & 94.7 \\
\hline
\end{tabular}

Source: own elaboration on the basis of data from Agency for Restructuring and Modernization of Agriculture and Local Data Bank of Central Statistical Office.

from the level of $111.2 \%$ to the level of $101.7 \%$. In seven provinces a decrease in GAV/EF with regards to the average national was noted while in the nine provinces this indicator increased.

Data concluded in Table 3 enable the testing of the flow of regions between the selected groups of regions on the basis of the levels of GAV/EF against the country average. Four groups of provinces were distinguished, two groups above average (I high level, II medium high level), while the value of 110.25 was assumed as the average, constituting an average for the years 2004-2006 and 2012-2014, below the average (III medium low level, IV low level). In the initial period, within the extreme groups, representing level I - high and IV - low -5 provinces were placed, while within the groups close to the average country level, 3 provinces were found (Table 4). In the final period of the analysis the end group with the highest level decreased from 5 to 4 , while III group - of the medium low level - increased from 3 to 4 provinces. The highest level of GAV, falling for the used funds from the European Funds, was obtained in the entire period by three provinces: Zachodniopomorskie, Mazowieckie, Warmińsko-Mazurskie and Wielkopolskie, whilst those with an initially high level of GAV/EF in the years 2004-2006 moved to the III level - medium low in the period of 2012-2014. Provinces: Podkarpackie, Lubelskie and Pomorskie in the entire period have continuously remained in group IV-low level of GAV/EF, while Podlaskie province exchanged its low position in the group IV with Małopolskie province from group III. Flows presented in Table 4 indicate 
Proceedings of the 2018 International Scientific Conference 'Economic Sciences for Agribusiness and Rural Economy' No 1, Warsaw, 7-8 June 2018, pp. 212-220

Table 3. Changes in the distribution of the level of gross added value translated into the obtained EU funds in the regions in comparison to the country Three year averages with regards to the country scale in $\%$ in the years 2004-2006 and 2012-2014

\begin{tabular}{|l|c|c|c|c|c|c|}
\hline Specification & $2004-2006$ & Group & $2012-2014$ & Group & $\begin{array}{c}\text { Change } \\
\text { (p.p.) }\end{array}$ & $\begin{array}{c}\text { Change } \\
(\%)\end{array}$ \\
\hline Dolnośląskie & 88.4 & IV & 73.5 & IV & -14.8 & -16.8 \\
\hline Kujawsko-pomorskie & 90.8 & III & 93.3 & III & 2.5 & 2.7 \\
\hline Lubelskie & 65.7 & IV & 75.4 & IV & 9.7 & 14.8 \\
\hline Lubuskie & 146.8 & I & 106.4 & III & -40.4 & -27.5 \\
\hline Lódzkie & 122.7 & II & 112.0 & II & -10.7 & -8.7 \\
\hline Małopolskie & 100.7 & III & 89.8 & IV & -10.9 & -10.9 \\
\hline Mazowieckie & 134.5 & I & 142.5 & I & 8.1 & 6.0 \\
\hline Opolskie & 99.3 & III & 90.3 & III & -9.1 & -9.1 \\
\hline Podkarpackie & 59.0 & IV & 54.6 & IV & -4.4 & -7.5 \\
\hline Podlaskie & 80.5 & IV & 97.0 & III & 16.6 & 20.6 \\
\hline Pomorskie & 63.2 & IV & 87.2 & IV & 24.0 & 37.9 \\
\hline Śląskie & 129.6 & II & 116.1 & II & -13.6 & -10.5 \\
\hline Świętokrzyskie & 121.6 & II & 121.9 & II & 0.3 & 0.2 \\
\hline Warmińsko-mazurskie & 133.5 & I & 152.7 & I & 19.1 & 14.3 \\
\hline Wielkopolskie & 130.1 & I & 169.5 & I & 39.4 & 30.3 \\
\hline Zachodniopomorskie & 178.7 & I & 199.8 & I & 21.1 & 11.8 \\
\hline Average & 109.1 & $\times$ & 111.4 & $\times$ & 2.3 & 2.1 \\
\hline Standard deviation & 33.6 & $\times$ & 38.3 & $\times$ & 4.7 & 13.9 \\
\hline Median & 111.2 & $\times$ & 101.7 & $\times$ & -9.5 & -8.5 \\
\hline
\end{tabular}

Source: own elaboration on the basis of data from Agency for Restructuring and Modernization of Agriculture and Local Data Bank of Central Statistical Office..

that the highest stability is a feature of group II - medium high level of GAV/EF.

Changes which occurred in this group brought the level of entire group upwards to the country average. However, deviations which occurred were not sufficiently strong to trigger the shift to the group from another level. To a certain degree, this group shows features of club convergence. The provinces belonging to the group of low level, such as Pomorskie and Lubelskie improved their ranking positions most strongly. So did the provinces belonging to group I - high level of GAV/EF (Wielkopolskie, Warmińsko-Mazurskie and Zachodniopomorskie). An unusual shift from group I to group III took place in case of Lubuskie province. Tendencies of increases in GAV towards the used funds, thus the tendency to catch up with the better ones, were revealed in case of three provinces of the fourth group with the lowest level of the discussed indicator. This might speak in favour of the occurrence of a phenomenon of beta-convergence.

The value of indicator of relative variability of GAV/EF amounted to 42.1\% in 2004 and until 2014 it dropped to the level of $22.3 \%$. The analysis of sigma indicator in the tested period suggests the convergence of regions. The direction value of the regres- 
Proceedings of the 2018 International Scientific Conference 'Economic Sciences for Agribusiness and Rural Economy' No 1, Warsaw, 7-8 June 2018, pp. 212-220

Table 4. Flows of regions between four groups of levels of GAV/EF in the regions of Poland with regards to the three year national average between the initial period and the end period of the analysis in the years 2004-2014

\begin{tabular}{|l|c|c|c|c|}
\hline \multirow{2}{*}{$\begin{array}{l}\text { Level of GAV/EF } \\
\text { in comparison to the national average }\end{array}$} & \multicolumn{2}{|c|}{ Number of regions in the years } & \multicolumn{2}{|c|}{ Balance of flows } \\
\cline { 2 - 5 } & $2004-2006$ & $2012-2014$ & \multicolumn{2}{|c|}{+ growth, loss } \\
\hline I high level $>130.0 \%$ & 5 & 4 & +0 & -1 (III) \\
\hline II medium high level $130.0 \%$ & 3 & 3 & +0 & -0 \\
\hline III medium low level $90.1-110.1 \%$ & 3 & 4 & +2 (I, IV) & -1 (IV) \\
\hline IV low level $<90.0 \%$ & 5 & 5 & +1 (III) & 1 (III) \\
\hline
\end{tabular}

Source: own elaboration on the basis of Table 3 .

sion line, relative variability coefficient of the level of GAV/EF assumed a negative value $(-1.11)$ which is confirmed by the convergence of regions (Fig. 1).

In the case of beta ratio analysis, a large increase in the voivodship indicator was observed, in which the GVA/EF logarithm was relatively low, as well as a very low increase in voivodships, whose initial GVA/ /EF value was high. The above situation confirms the occurrence of the convergence of regions (Fig. 2).

The highest correlation coefficient between GVA and co-financing from EU funds in the years
2004-2014 was recorded in the case of Mazowieckie province $(\mathrm{r}=0.92)$, Lubelskie province $(\mathrm{r}=0.89)$ and Śląskie province $(\mathrm{r}=0.86)$. The lowest values were recorded for Wielkopolskie province $(\mathrm{r}=0.56)$, Małopolskie province $(\mathrm{r}=0.59)$ and Kujawsko-Pomorskie province $(r=0.63)$. Nevertheless, in each case the correlation coefficient was positive and relatively high. When analysing the relation between GVA for the entire Poland and the sum of funds obtained for agriculture in 2004-2014, a high positive correlation (0.87) was demonstrated (Fig. 3).

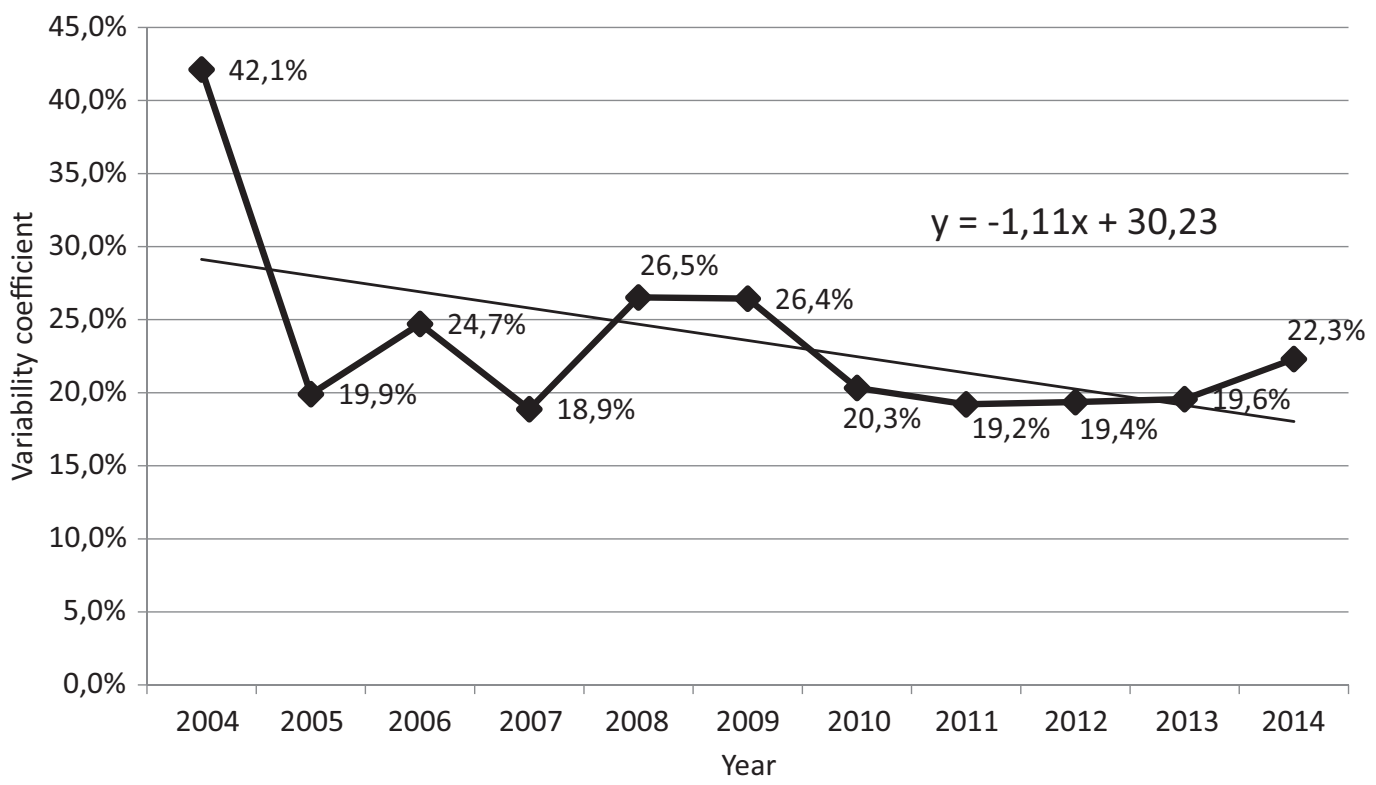

Figure 1. Analysis of sigma-convergence of gross value added per funds obtained from EF 2004-2014

Source: own elaboration based on data from the Agency for Restructuring and Modernization of Agriculture and Local Data Bank of Central Statistical Office. 


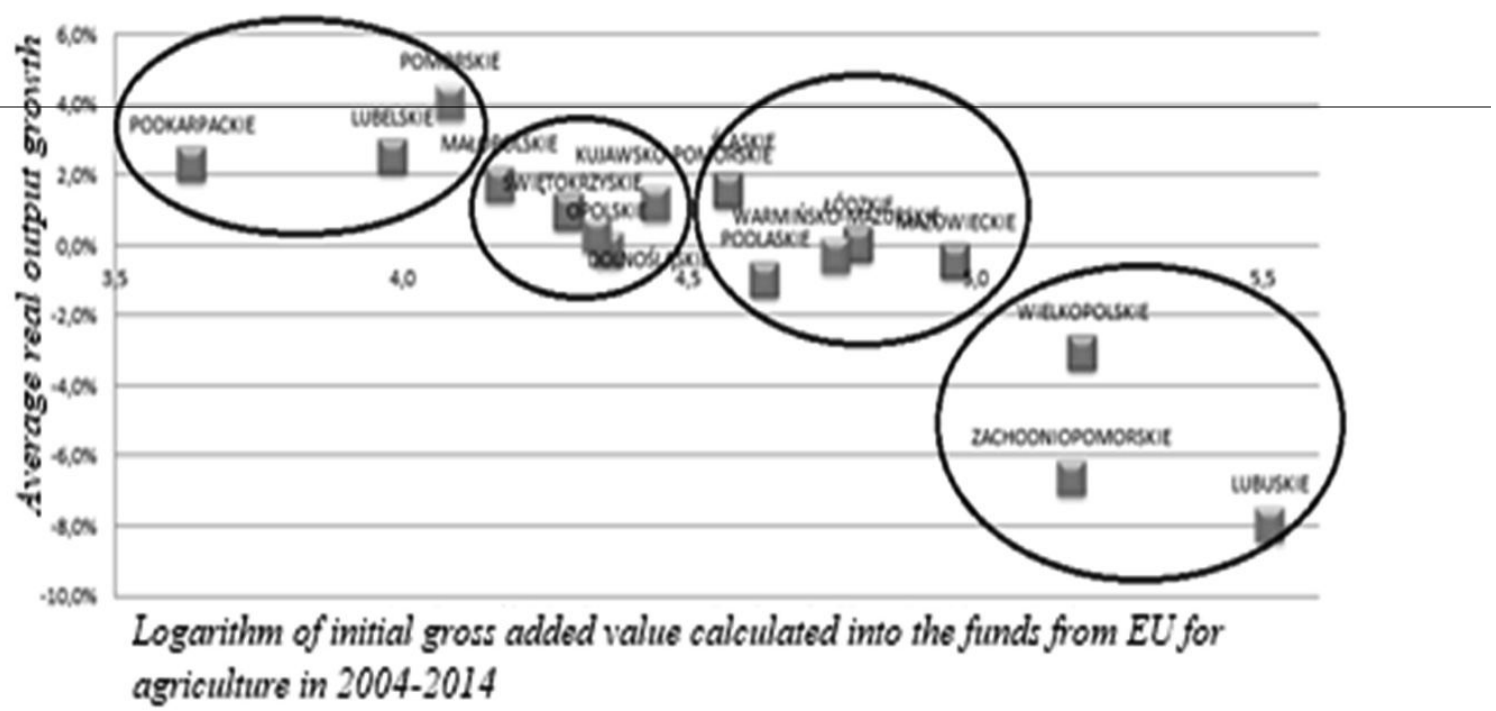

Figure 2. Analysis of beta-convergence of gross value added per EU funds acquired in Poland by province Source: own elaboration based on data from the Agency for Restructuring and Modernization of Agriculture and Local Data Bank of Central Statistical Office.

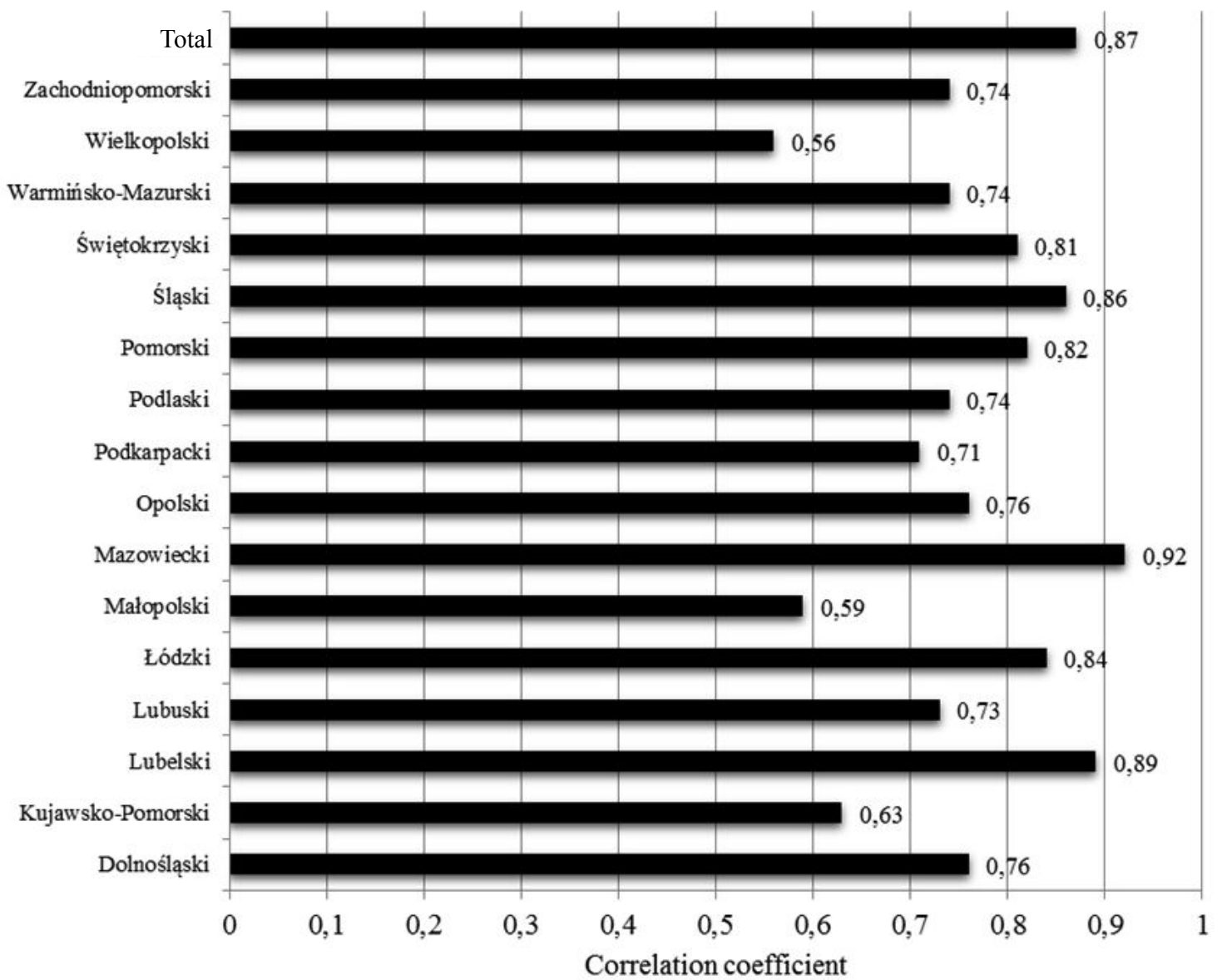

Figure 3. The correlation coefficient of gross value added and funds obtained from the EU by agriculture in the years 2004-2014 for regions

Source: own elaboration based on data from the Agency for Restructuring and Modernization of Agriculture and Local Data Bank of Central Statistical Office. 


\section{CONCLUSIONS}

1. Reducing development disparities between countries and regions is one of the most important general goals of European integration. The Community budget established for this purpose is directed to individual countries and regions by means of various European funds and policies. The task of these policies and funds is to support the development of countries and regions that are lagging behind in development, which may result in the occurrence of phenomenon of convergence. One of the most supported economic sectors is agriculture and other forms of farming in rural areas. In Poland, agriculture and other rural sectors of all regions benefited from the support of the common agricultural policy and cohesion policy. In this work it was assumed that support for agriculture, forestry, hunting and fisheries is a factor contributing to regional convergence in Poland.

2. The research confirmed the positive correlation between the gross value added of the natural sectors of the rural economy and the amount of appropriations from European funds used by the regions for the development of agriculture and rural areas. The correlation coefficient in the country was 0.87 and ranged from 0.56 in the Wielkopolskie province to 0.92 in the Mazowieckie province. High correlation indicators show strong relationship between management effects in all regions of Poland and the level of utilization of EU funds for the development of agriculture and rural areas.

3. The study of the productivity expressed by the level of Gross Value Added (GVA) obtained in the sectors of section A: agriculture, forestry, hunting, and fisheries, in relation to the value of funds received from the European Union (EF) and used for the development of agriculture and rural areas, confirmed the occurrence of the phenomenon of sigma-convergence and beta-convergence. In 2004-2014, in the regions of Poland the coefficient of relative GVA/EF value became negative: -1.1 , which confirms the reduction of the coefficient of variation from $42.1 \%$ in 2004 to $22.3 \%$ in 2014. The direction of the regression line in re- lation to the value of the GVA/EF coefficient of variation indicates the occurrence of convergence of regions in the studied range.

4. The occurrence of the is indicated by a lower initial level of the logarithm of GVA/EF coefficients in regions with high growth rate and a higher initial level of this logarithm in regions with a negative real growth rate. This results in a slight but noticeable limitation of regional differentiation by catching up by regions considered to be less advanced in the studied range.

5. The change of the existing productivity pattern of regions at the beginning of the examined period was not dynamic. Regions with a little higher than average level of GVA/EF demonstrated a kind of particular stability. The group of provinces with a highest level of the GVA/EF indicator decreased, while the largest shift between province groups occurred in groups of provinces representing the productivity level lower than the average in national scale.

\section{REFERENCES}

1. Adamowicz, M., Szepeluk, A. (2018). Środki Unii Europejskiej jako źródło konwergencji regionalnej rolnictwa w Polsce [European Union Funds as a source for regional convergence of agriculture in Poland). Roczniki Naukowe SERiA, 2, pp. 1-8.

2. Barath, L., Fertö, L. (2017). Productivity and convergence in European agriculture. Journal Agricultural Economics, 68 (1), pp. 228-248.

3. Czyżewski, A., Kułyk, P. (2009). Konwergencja czy dywergencja mechanizmów wsparcia sektora rolnego [Convergence or divergence of support mechanisms for agriculture]. Zeszyty Naukowe SGGW w Warszawie. Problemy Rolnictwa Światowego, 8, pp. 41-51.

4. Hamulczuk, M. (2015). Total factor productivity convergence in the EU agriculture. In: Competitiveness of Agro-Food and Environmental Economy. Faculty of Agro-Food and Environmental Economics, Bucharest University of Economic Studies Bucharest, pp. 34-43.

5. Niewiadomski, K. (2009). Ocena konwergencji rolnictwa w Polsce w latach 1998-2005 [Evaluation of agriculture convergence in Poland in 1998-2005]. Wieś i Rolnictwo, 3 (144), pp. 49-62.

6. Nowak, A. (2007). Przestrzenne zróżnicowanie zmian produktywności całkowitej rolnictwa w Polsce w latach 
2005-2014 [Spatial differences of changes in total agricultural productivity in Poland during 2005-2014]. Roczniki Naukowe SERiA, 1, pp. 131-136.

7. Sapa, A., Baer-Nawrocka, A. (2014). Konwergencja wydajności pracy w rolnictwie a intensywność handlu rolno-żywnościowego w amerykańskich ugrupowaniach handlowych [Convergence of labour productivity in agriculture and intensity of agro-food trade in American Trade Associations]. Gospodarka Narodowa, 3, pp. 111-131.
8. Smędzik Ambroży, K. (2014). Konwergencja czy dywergencja rolnictwa w Polsce w latach 2004-2011 [Convergence or divergence of agriculture in Poland during 2004-2011]. In: IX Kongres Ekonomistów Polskich, pp. 1-11.

9. Wójcik, P. (2008). Dywergencja czy konwergencja: dynamika rozwoju polskich regionów [Divergence or convergence: the development dynamics of Polish regions]. Studia Regionalne i Lokalne, 2 (32), pp. 41-60. 